Original research article

\title{
Our initial experience with ventriculo-epiplooic shunt in treatment of hydrocephalus in two centers
}

\section{Valentin Titus Grigorean ${ }^{a}$, Aurelia Mihaela Sandu ${ }^{b, *}$, Mihai Popescu ${ }^{c}$, Ioan Stefan Florian ${ }^{d}$, Cristian Dumitru Lupascu ${ }^{e}$, Corina Lupascu Ursulescu ${ }^{e}$}

a University of Medicine and Pharmacy "Carol Davila", Department of General Surgery, Emergency Clinical Hospital Bagdasar-Arseni, Bucharest, Romania

${ }^{\mathrm{b}}$ Fourth Department of Neurosurgery, Emergency Clinical Hospital Bagdasar-Arseni, Bucharest, Romania

${ }^{c}$ University Pitesti, Department of Neurosurgery, Emergency County Hospital Arges, Pitesti, Romania

dUniversity of Medicine and Pharmacy "Iuliu Hatieganu", Cluj-Napoca, Romania

e University of Medicine and Pharmacy "Grigore T. Popa", Emergency County Hospital St. Spiridon, Iasi, Romania

\section{A R T I C L E I N F O}

Article history:

Received 14 September 2016

Accepted 26 April 2017

Available online 11 May 2017

Keywords:

Epiploon

Greater omentum

Hydrocephalus

Ventriculo-epiplooic shunt

Ventriculo-peritoneal shunt failure

\begin{abstract}
A B S T R A C T
Introduction: Hydrocephalus represents impairment in cerebrospinal fluid (CSF) dynamics. If the treatment of hydrocephalus is considered difficult, the repeated revisions of ventriculoperitoneal (VP) shunts are even more challenging.

Objective: The aim of this article is to evaluate the efficiency of ventriculo-epiplooic (VEp) shunt as a feasible alternative in hydrocephalic patients.

Material and methods: A technical modification regarding the insertion of peritoneal catheter was imagined: midline laparotomy $8-10 \mathrm{~cm}$ long was performed in order to open the peritoneal cavity; the great omentum was dissected between its two layers; we placed the distal end of the catheter between the two epiplooic layers; a fenestration of $4 \mathrm{~cm}$ in diameter into the visceral layer was also performed.

A retrospective study of medical records of 15 consecutive patients with hydrocephalus treated with VEp shunt is also presented.

Results: Between 2008 and 2014 we performed VEp shunt in 15 patients: 5 with congenital hydrocephalus, 8 with secondary hydrocephalus and 2 with normal pressure hydrocephalus. There were 7 men and 8 women. VEp shunt was performed in 13 patients with multiple distal shunt failures and in 2 patients, with history of abdominal surgery, as de novo extracranial drainage procedure. The outcome was favorable in all cases, with no significant postoperative complications.
\end{abstract}

\footnotetext{
* Corresponding author at: Fourth Department of General Surgery, Emergency Clinical Hospital Bagdasar-Arseni, Bucharest, Romania, Address: Emergency Clinical Hospital Bagdasar-Arseni, Department of Neurosurgery, No. 12 Berceni Road, District 4, Bucharest, 041902, Romania.

E-mail address: aurasandu@gmail.com (A.M. Sandu).

http://dx.doi.org/10.1016/j.pjnns.2017.04.007

0028-3843/@ 2017 Polish Neurological Society. Published by Elsevier Sp. z o.o. All rights reserved.
} 
Conclusions: VEp shunt is a new, safe and efficient surgical technique for the treatment of hydrocephalus. VEp shunt is indicated in patients with history of recurrent distal shunt failures, and in patients with history of open abdominal surgery and high risk for developing abdominal complications.

๔ 2017 Polish Neurological Society. Published by Elsevier Sp. z o.o. All rights reserved.

\section{Introduction}

The real incidence of hydrocephalus in the general population is as of yet uncertain, the prevalence being estimated at $1-1.5 \%$ [1-3], while gender distribution is considered equal. Age distribution has two peaks: the first during infancy, predominantly congenital hydrocephalus, whereas the second peak is found in adults, where normal pressure hydrocephalus is encountered [2].

If not properly treated, hydrocephalus signifies high morbidity and mortality, causing severe and permanent neurological consequences. The cumulative costs implied for the diagnosis and treatment of these patients are often insurmountable [4].

Management of hydrocephalus is a challenging endeavor, numerous therapies having been devised across history. To this day, surgery remains the treatment of choice for hydrocephalus, no medical remedy being effective. Several surgical techniques have been described, grouped as internal, external or extracranial drainages. Third ventriculostomy, first reported by Dandy and later improved by Stookey and Scarff [5], belongs to the internal drainage techniques. External ventricular drainage (EVD) can only be utilized for a limited amount of time. Extracranial ventricular drainages are among the most frequently used in the treatment of hydrocephalus. They are represented by VP shunt, ventriculoatrial shunt, lumboperitoneal shunt and ventriculopleural shunt. From a historical perspective, other drainages have been reported that are currently abandoned or rarely used, such as the ventriculosubgaleal shunt, ventriculocholecystic shunt, ventriculoureteral shunt, lumboureteral shunt, ventriculomastoid drainage, ventriculosternal shunt, drainage into the thoracic duct, salivary gland, spinal epidural space, bone stomach, ileum and fallopian tube [2,6-12]. Ventriculosinusal shunts, such as ventriculosagittal [13] or ventriculotransverse shunts [14], being considered anatomically and physiologically the most appropriate treatment of this disease, have also been attempted. We previously reported the ventriculo-epiplooic (VEp) shunting in animal models [15].

The objective of this study is to report our initial experience with the VEp shunt in human patients, and review the surgical technique. We also aim to establish the indications, emphasize the advantages compared with the standard VP shunt, and evaluate its efficiency and safety by analyzing immediate and long-term results.

\section{Material and methods}

We retrospectively reviewed medical records of consecutive patients with positive diagnosis of hydrocephalus, in which we had performed VEp shunts between February 2008 and July 2014 , in two centers. In order to perform VEp shunt, we used a basic shunt tray and a cerebrospinal fluid (CSF) drainage system: ventricular catheter, peritoneal catheter, and valve (high, medium, low or programmable) or connector.

The surgical technique is standard for the cranial step (lateral ventricle catheterization) and subcutaneous tunneling carried from the right retromastoidian region, right anterolateral side of the neck, anterior thorax on the midclavicular line to the mid-anterior abdomen, and distal tube insertion into this subcutaneous tunnel. The abdominal step had a few differences from the classical VP shunt procedure. First, a midline laparotomy of 8-10 cm in length was performed, and then the peritoneal cavity was opened, revealing the greater omentum. Next, a dissection between the two layers of the great omentum was performed and the distal end of the catheter was placed between these two layers, in a declivitous position. The catheter was fixed in place with a simple suture. An epiplooic fenestration in the visceral layer, $4 \mathrm{~cm}$ in diameter, was also produced. Surgery was concluded with careful hemostasis and parietoraphy in anatomical layers.

\section{Results}

Between February 2008 and July 2014 we performed VEp shunts in 15 patients with hydrocephalus. We performed VEp shunt 13 patients with prior VP shunt and multiple distal shunt failures with shunt revisions, varying in number from 1 to 38. In two cases with nonfunctional third ventriculostomy, we practiced VEp shunt as a first extracranial drainage procedure, without attempting a VP shunt beforehand (Table 1).

We performed it in all types of hydrocephalus, thus 5 patients had congenital hydrocephalus, 8 patients had secondary hydrocephalus and 2 patients had normal pressure hydrocephalus. There were 7 men and 8 women.

All patients with congenital hydrocephalus were diagnosed during the first year of life. Patients with congenital hydrocephalus also presented additional developmental anomalies, such as porencephalic cyst in two cases, agenesis of the corpus callosum and pineal region cyst in two cases, posterior fossa arachnoid cyst, Dandy-Walker malformation in one case, and a Chiari II malformation with associated lumbar meningomyelocele. This stands as evidence that congenital hydrocephalus occurs in the complex context of developmental anomalies. In all five patients, VP shunt was performed as first choice therapy in the first year of life. These five patients belong to a special group of patients with repetitive VP shunt failures and multiple shunt revisions. Before the VEp shunt attempt, the number of shunt revisions was impressive 
Table 1 - Patients with VEp shunt for hydrocephalus.

Sex and

age
Diagnosis
Signs and

symptoms
VEp shunt

\begin{tabular}{|c|c|c|c|c|c|c|c|c|c|c|c|c|}
\hline & & & \multirow{2}{*}{\multicolumn{5}{|c|}{ Before VEp shunt }} & \multirow{2}{*}{\multicolumn{5}{|c|}{ After VEp shunt }} \\
\hline & & & & & & & & & & & & \\
\hline & & & \multirow{2}{*}{$\begin{array}{l}\text { First surgery for } \\
\text { hydrocephalus }\end{array}$} & \multirow{2}{*}{$\begin{array}{l}\text { No of } \\
\text { revi- } \\
\text { sions }\end{array}$} & \multicolumn{2}{|c|}{ Shunt failure } & \multirow{2}{*}{$\begin{array}{l}\text { Causes of distal } \\
\text { shunt failure }\end{array}$} & \multirow[t]{2}{*}{$\mathrm{Age}^{\dagger}$} & \multirow{2}{*}{$\begin{array}{l}\text { No of } \\
\text { revi- } \\
\text { sions }^{1 / 2}\end{array}$} & \multirow{2}{*}{$\begin{array}{l}\text { Cause of } \\
\text { failure }\end{array}$} & \multirow{2}{*}{$\begin{array}{l}\text { Out- } \\
\text { come }\end{array}$} & \multirow{2}{*}{$\begin{array}{l}\text { Follow- } \\
\text { up }\end{array}$} \\
\hline & & & & & $\begin{array}{l}\text { Proximal + } \\
\text { valve }\end{array}$ & Distal & & & & & & \\
\hline $\mathrm{m}, 7 \mathrm{mo}$ & $\begin{array}{l}\text { Congenital } \\
\text { hydrocephalus, right T } \\
\text { porencephalic cyst, left } \\
\text { hemiparesis }\end{array}$ & $\begin{array}{l}\text { Increased head } \\
\text { circumference, } \\
\text { altered mental state, } \\
\text { vomiting, left } \\
\text { hemiparesis }\end{array}$ & Cysto-VP shunt in $\mathrm{Y}$ & 23 & 9 & 14 & $\begin{array}{l}\text { CSF pseudocysts } \\
\text { Extensive peritoneal } \\
\text { adherences } \\
\text { syndrome }\end{array}$ & $6 y$ & 0 & - & Good & 7 y 3 mo \\
\hline $\mathrm{m}, 5 \mathrm{mo}$ & $\begin{array}{l}\text { Congenital } \\
\text { hydrocephalus, left } \\
\text { porencephalic cyst, right } \\
\text { hemiparesis }\end{array}$ & $\begin{array}{l}\text { Increased head } \\
\text { circumference, } \\
\text { altered mental state, } \\
\text { vomiting, right } \\
\text { hemiparesis }\end{array}$ & Cysto-VP shunt in $\mathrm{Y}$ & 28 & 14 & 14 & $\begin{array}{l}\text { CSF pseudocysts } \\
\text { Extensive peritoneal } \\
\text { adherences } \\
\text { syndrome }\end{array}$ & $7 \mathrm{y}$ & 0 & - & Good & 6 y $10 \mathrm{mo}$ \\
\hline $\mathrm{m}, 6 \mathrm{mo}$ & $\begin{array}{l}\text { Congenital } \\
\text { hydrocephalus, pineal } \\
\text { cyst, Dandy-Walker } \\
\text { malformation, agenesis } \\
\text { of corpus callosum }\end{array}$ & $\begin{array}{l}\text { Increased head } \\
\text { circumference, } \\
\text { altered mental state, } \\
\text { vomiting, }\end{array}$ & VP shunt & 21 & 12 & 9 & $\begin{array}{l}\text { CSF pseudocysts } \\
\text { Extensive peritoneal } \\
\text { adherences } \\
\text { syndrome }\end{array}$ & $6 y$ & 1 & $\begin{array}{l}\text { Ventricular } \\
\text { catheter and } \\
\text { valve occlusion } \\
\text { with debrides }\end{array}$ & Good & 4 y $11 \mathrm{mo}$ \\
\hline f, $8 \mathrm{mo}$ & $\begin{array}{l}\text { Congenital } \\
\text { hydrocephalus, } \\
\text { posterior fossa } \\
\text { arachnoid cyst, pineal } \\
\text { region cystic tumor, } \\
\text { agenesis of the corpus } \\
\text { callosum, ventriculitis } \\
\text { with Acinetobacter } \\
\text { baumannii, obesity, } \\
\text { depressive syndrome }\end{array}$ & $\begin{array}{l}\text { Altered mental state, } \\
\text { somnolence, } \\
\text { vomiting, Parinaud } \\
\text { syndrome, bilateral } \\
\text { III nerve palsy }\end{array}$ & $\begin{array}{l}\text { VP shunt, posterior } \\
\text { fossa cystotomy, left } \\
\text { frontal Ommaya } \\
\text { reservoir for pineal } \\
\text { tumor }\end{array}$ & 38 & 23 & 16 & $\begin{array}{l}\text { CSF pseudocysts } \\
\text { Extensive peritoneal } \\
\text { adherences } \\
\text { syndrome }\end{array}$ & $21 \mathrm{y}$ & 1 & $\begin{array}{l}\text { Ventricular } \\
\text { catheter } \\
\text { occlusion with } \\
\text { debrides }\end{array}$ & Good & $4 \mathrm{y}$ \\
\hline f, $1 \mathrm{mo}$ & $\begin{array}{l}\text { Congenital } \\
\text { hydrocephalus, Chiari II } \\
\text { malformation, operated } \\
\text { lumbar } \\
\text { myelomeningocele }\end{array}$ & $\begin{array}{l}\text { Altered neurological } \\
\text { state, increased ICP, } \\
\text { vision disturbances }\end{array}$ & $\begin{array}{l}\text { Right VP shunt, left } \\
\text { VP shunt }\end{array}$ & 12 & 4 & 8 & $\begin{array}{l}\text { CSF pseudocysts } \\
\text { Extensive peritoneal } \\
\text { adherences } \\
\text { syndrome }\end{array}$ & $7 y$ & 0 & - & Good & 2 y 7 mo \\
\hline$f, 42 y$ & $\begin{array}{l}\text { Secondary } \\
\text { hydrocephalus after } \\
\text { operated colloid cyst. } \\
\text { Hysterectomy. }\end{array}$ & $\begin{array}{l}\text { Headache, nausea, } \\
\text { vomiting }\end{array}$ & $\begin{array}{l}\text { Third } \\
\text { ventriculostomy }\end{array}$ & 0 & - & - & - & $45 \mathrm{y}$ & 0 & - & Good & 7 y 1 mo \\
\hline$f, 8 y$ & $\begin{array}{l}\text { Secondary } \\
\text { hydrocephalus after } \\
\text { operated right cerebellar } \\
\text { pilocytic astrocytoma }\end{array}$ & $\begin{array}{l}\text { Headache, vomiting, } \\
\text { right-side balance } \\
\text { and coordination } \\
\text { disturbances }\end{array}$ & $\begin{array}{l}\text { VP shunt, total } \\
\text { resection of the right } \\
\text { cerebellar pilocytic } \\
\text { astrocytoma }\end{array}$ & 7 & 1 & 6 & $\begin{array}{l}\text { CSF pseudocysts } \\
\text { Extensive peritoneal } \\
\text { adherence syndrome }\end{array}$ & $11 \mathrm{y}$ & 0 & - & Good & 6 y 6 mo \\
\hline
\end{tabular}




\begin{tabular}{|c|c|c|c|c|c|c|c|c|c|c|c|c|}
\hline \multirow{4}{*}{$\begin{array}{l}\text { Sex and } \\
\text { age* }\end{array}$} & \multirow[t]{4}{*}{ Diagnosis } & \multirow{4}{*}{$\begin{array}{l}\text { Signs and } \\
\text { symptoms }\end{array}$} & \multicolumn{10}{|c|}{ VEp shunt } \\
\hline & & & \multicolumn{5}{|c|}{ Before VEp shunt } & \multicolumn{5}{|c|}{ After VEp shunt } \\
\hline & & & \multirow{2}{*}{$\begin{array}{l}\text { First surgery for } \\
\text { hydrocephalus }\end{array}$} & \multirow{2}{*}{$\begin{array}{l}\text { No of } \\
\text { revi- } \\
\text { sions }^{\ddagger}\end{array}$} & \multicolumn{2}{|c|}{ Shunt failure } & \multirow{2}{*}{$\begin{array}{l}\text { Causes of distal } \\
\text { shunt failure }\end{array}$} & \multirow{2}{*}{ Age $^{\dagger}$} & \multirow{2}{*}{$\begin{array}{l}\text { No of } \\
\text { revi- } \\
\text { sions }^{1 / 2}\end{array}$} & \multirow{2}{*}{$\begin{array}{l}\text { Cause of } \\
\text { failure }\end{array}$} & \multirow{2}{*}{$\begin{array}{l}\text { Out- } \\
\text { come }\end{array}$} & \multirow{2}{*}{$\begin{array}{l}\text { Follow- } \\
\text { up }\end{array}$} \\
\hline & & & & & $\begin{array}{l}\text { Proximal }+ \\
\text { valve }\end{array}$ & Distal & & & & & & \\
\hline f, $50 \mathrm{y}$ & $\begin{array}{l}\text { Secondary } \\
\text { hydrocephalus after } \\
\text { nonaneurysmal SAH. } \\
\text { Cholecystectomy. } \\
\text { Appendectomy }\end{array}$ & $\begin{array}{l}\text { Headache, nausea, } \\
\text { vomiting }\end{array}$ & $\begin{array}{l}\text { Third } \\
\text { ventriculostomy }\end{array}$ & 0 & - & - & - & $51 \mathrm{y}$ & 0 & - & Good & 6 y $1 \mathrm{mo}$ \\
\hline f, 44 y & $\begin{array}{l}\text { Secondary } \\
\text { hydrocephalus after } \\
\text { ruptured basilar tip } \\
\text { aneurysm }\end{array}$ & $\begin{array}{l}\text { Headache, nausea, } \\
\text { vomiting, } \\
\text { meningismus }\end{array}$ & $\begin{array}{l}\text { VP shunt, coils } \\
\text { embolization of the } \\
\text { basilar tip aneurysm }\end{array}$ & 1 & - & 1 & $\begin{array}{l}\text { Distal shunt } \\
\text { occlusion with } \\
\text { debrides }\end{array}$ & $46 \mathrm{y}$ & 0 & - & Good & 5 y $9 \mathrm{mo}$ \\
\hline $\mathrm{m}, 56 \mathrm{y}$ & $\begin{array}{l}\text { Secondary } \\
\text { hydrocephalus after } \\
\text { operated left vestibular } \\
\text { schwannoma, left } \\
\text { hipoacusia }\end{array}$ & $\begin{array}{l}\text { Headache, vomiting, } \\
\text { left hipoacusia }\end{array}$ & $\begin{array}{l}\text { VP shunt, subtotal } \\
\text { resection of the left } \\
\text { ventibular } \\
\text { schwannoma }\end{array}$ & 2 & 0 & 2 & $\begin{array}{l}\text { Extensive peritoneal } \\
\text { adherence syndrome }\end{array}$ & $58 \mathrm{y}$ & 0 & - & Good & 4 y 8 mo \\
\hline f, 32 y & $\begin{array}{l}\text { Secondary } \\
\text { hydrocephalus after } \\
\text { meningitis }\end{array}$ & $\begin{array}{l}\text { Headache, altered } \\
\text { mental state, } \\
\text { meningismus }\end{array}$ & VP shunt & 4 & 2 & 2 & CSF pseudocysts & $34 \mathrm{y}$ & 0 & - & Good & 4 y $5 \mathrm{mo}$ \\
\hline $\mathrm{m}$, at birth & $\begin{array}{l}\text { Secondary } \\
\text { hydrocephalus, } \\
\text { thalamic hemorrhage at } \\
\text { birth }\end{array}$ & $\begin{array}{l}\text { Altered general } \\
\text { status, tetraparesis, } \\
\text { vegetative state }\end{array}$ & $\begin{array}{l}\text { DVE, cysto-VP shunt } \\
\text { in } Y\end{array}$ & 17 & 11 & 6 & $\begin{array}{l}\text { Extensive peritoneal } \\
\text { adherences } \\
\text { syndrome }\end{array}$ & $7 \mathrm{y}$ & 0 & - & Stationary & $2 \mathrm{y}$ \\
\hline$f, 65$ y & $\begin{array}{l}\text { Secondary } \\
\text { hydrocephalus after } \\
\text { SAH }\end{array}$ & $\begin{array}{l}\text { Somnolence, } \\
\text { confusion, increased } \\
\text { ICP }\end{array}$ & VP shunt & 2 & 0 & 2 & $\begin{array}{l}\text { Repeated abdominal } \\
\text { surgeries } \\
\text { CSF pseudocysts }\end{array}$ & $66 \mathrm{y}$ & 0 & - & Good & $2 \mathrm{y}$ \\
\hline $\mathrm{m}, 67 \mathrm{y}$ & $\begin{array}{l}\text { Normal pressure } \\
\text { hydrocephalus }\end{array}$ & $\begin{array}{l}\text { Gait disturbances, } \\
\text { memory loss, gatism }\end{array}$ & VP shunt & 2 & 1 & 1 & $\begin{array}{l}\text { Distal shunt } \\
\text { occlusion with } \\
\text { debrides }\end{array}$ & $68 \mathrm{y}$ & 0 & - & Good & 4 y 4 mo \\
\hline $\mathrm{m}, 70 \mathrm{y}$ & $\begin{array}{l}\text { Normal pressure } \\
\text { hydrocephalus }\end{array}$ & $\begin{array}{l}\text { Gait disturbances, } \\
\text { memory loss, gatism }\end{array}$ & VP shunt & 1 & - & 1 & $\begin{array}{l}\text { Distal shunt } \\
\text { occlusion with } \\
\text { debrides }\end{array}$ & $70 \mathrm{y}$ & 0 & - & Good & 4 y $10 \mathrm{mo}$ \\
\hline \multicolumn{13}{|c|}{$\begin{array}{l}\text { Age at diagnosis of hydrocephalus. } \\
\text { Age at VEp shunt. } \\
\text { No of revisions: numbers of shunt revision before VEp shunt. } \\
1 / 2 \text { No of revisions: number of revisions after VEp shun. }\end{array}$} \\
\hline
\end{tabular}


varying from 12 to 38 , over a period of time that varied from 5 to 20 years. The causes of distal shunt failure were CSF pseudocysts or extensive peritoneal adherence syndrome. After repeated distal shunt failure, we performed the VEp shunt. Age at VEp shunt varied from 6 to 21 years.

Eight patients had a positive diagnosis for secondary hydrocephalus. The cause of hydrocephalus was operated brain tumors in three cases, such as: cerebellar pilocytic astrocytoma, vestibular schwannoma and colloid cyst. In four instances, hydrocephalus was the consequence of intracranial hemorrhage, in three of them subarachnoid hemorrhage (SAH) was noted (in two cases as a consequence of aneurysmal rupture) and in one patient, a thalamic hematoma with consecutive intraventricular hemorrhage was recorded. The remaining case had hydrocephalus secondary to meningitis. In five cases hydrocephalus was first treated with VP shunt. In the case with intraventricular hemorrhage, the VP shunt was performed after a period of EVD. After repeated distal shunt failures, varying from 1 to 17, over a period of time of 1 to 7 years VEp shunt was performed. Distal VP shunt complications were represented by CSF pseudocysts, extensive peritoneal adherence syndrome or distal shunt occlusion with debrides. In two patients third ventriculostomy was performed as a first choice treatment. After 1 and 3 years, respectively, they presented recurrence of symptoms, while cerebral MRI showed no flow-related signal void in the floor of the third ventricle. Age in this group of patients varied significantly (Figs. 1-6).

Normal pressure hydrocephalus was present in two cases. In both of them, the first treatment was represented by VP shunt. After several shunt failures, we chose to perform VEp shunt. Age was higher than in previous types of hydrocephalus.

The follow-up period varied from 24 to 87 months. VEp shunt surgery had no mortality. No distal shunt failure was encountered in this series after VEp shunt. Only two patients presented proximal shunt failure. The outcome was favorable

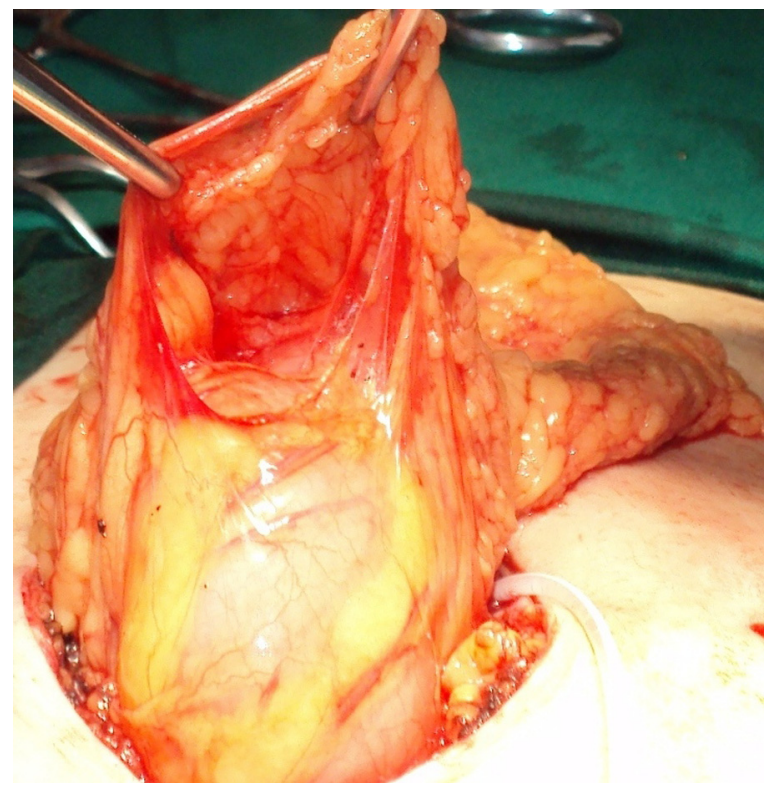

Fig. 1 - Intraoperative aspect showing greater omentum.

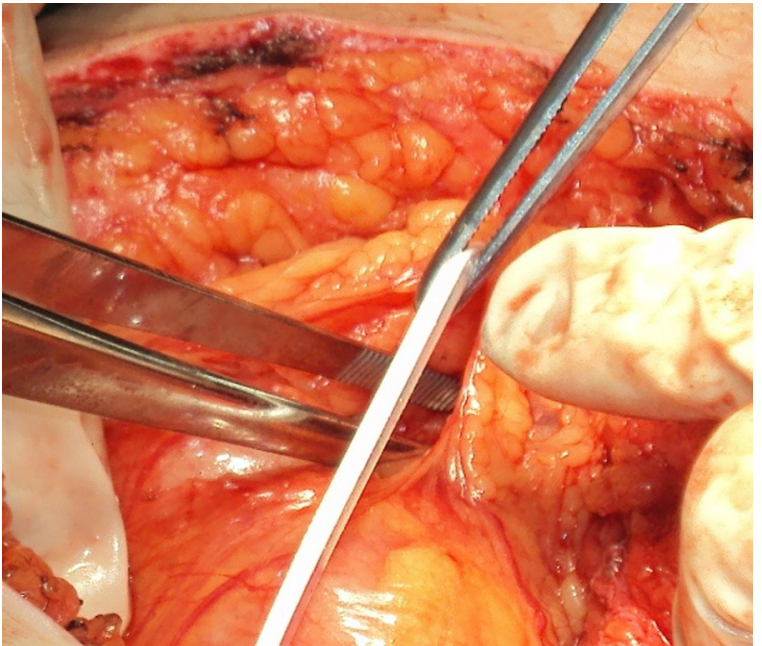

Fig. 2 - Intraoperative aspect. Introducing the distal tip of the catheter between the two epiplooic layers.

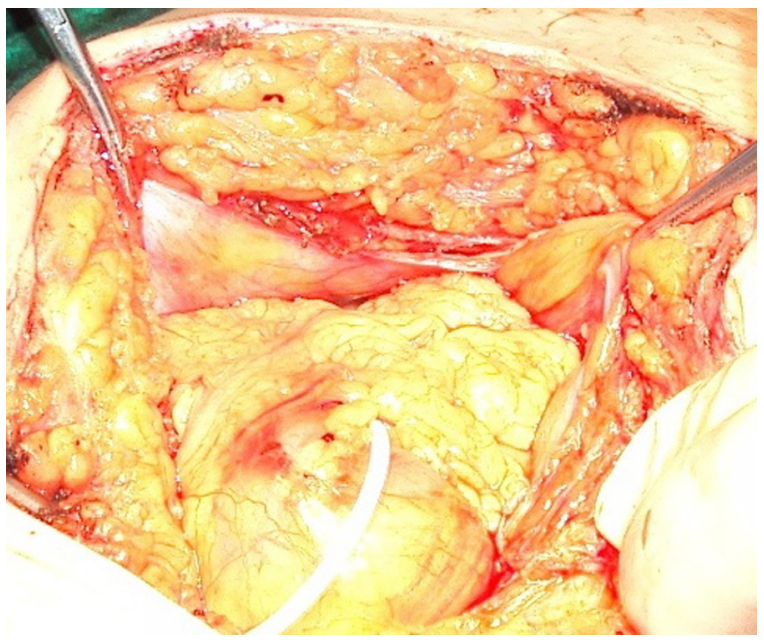

Fig. 3 - Intraoperative aspect. Final aspect, with distal shunt introduced between epiplooic layers.

in 14 cases, with no significant postoperative complications. No additional neurological deficits were manifest. One patient, with intraventricular and thalamic hemorrhage at birth and secondary hydrocephalus developed vegetative state, but even he did not have distal shunt malfunction.

The limit of this study is represented by a relatively small number of patients.

\section{Discussions}

Nowadays, VP shunt is the most common surgical procedure for the treatment of hydrocephalus. The abdominal step of VP shunt is represented by the placement of the distal end of the peritoneal catheter into the peritoneal cavity, either by open surgery, or by using the trocar. In both techniques, the distal end of the catheter is introduced through a small peritoneal breach, located lateral and superior to the umbilicus on the right midclaviculary line, and then a sufficiently long portion 


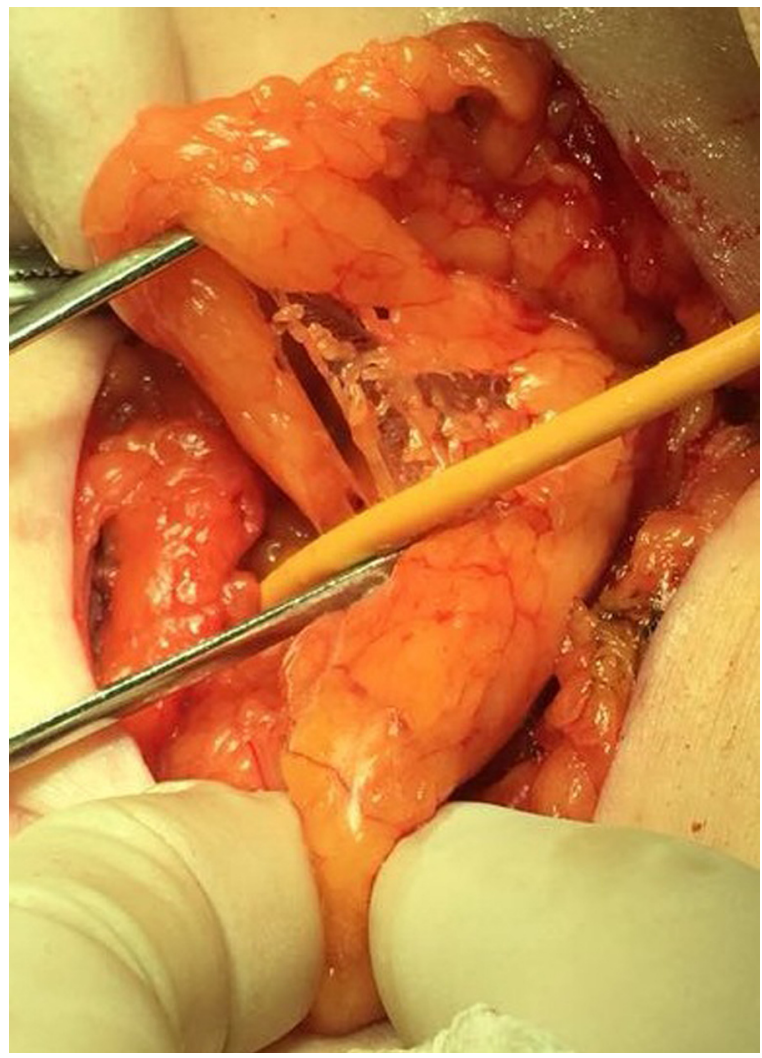

Fig. 4 - Intraoperative aspect. Introducing the distal tip of the catheter between the two epiplooic layers.

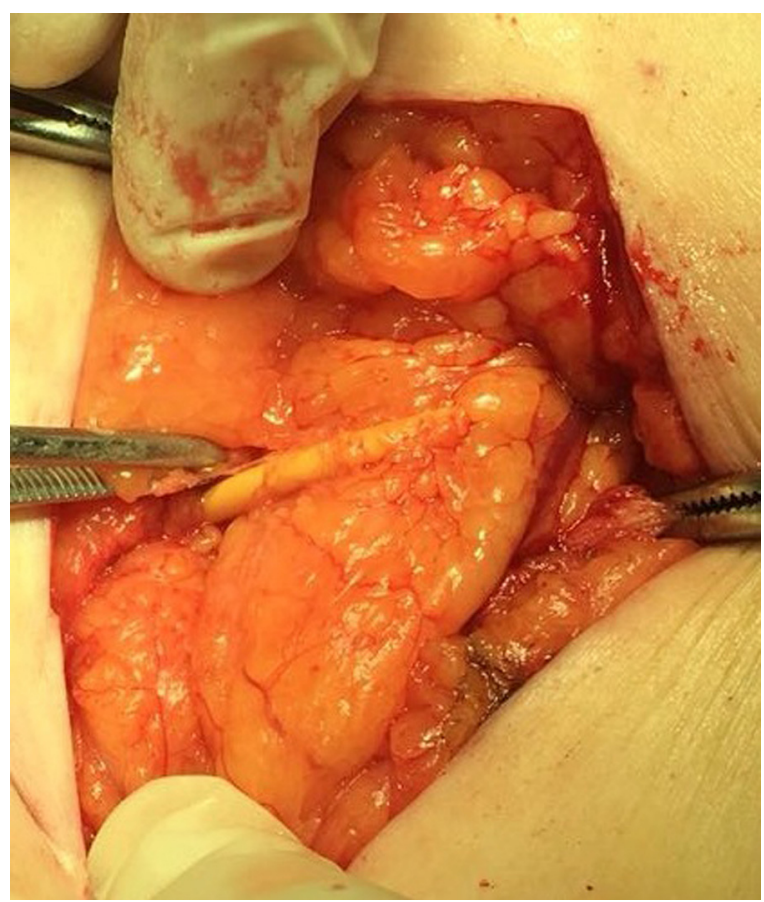

Fig. 5 - Intraoperative aspect. Placement of the distal catheter between the layers of the greater omentum.

of the catheter is delivered inside, floating freely between intestinal loops, this currently being its most regular placement site. However, over the years, other intraperitoneal sites

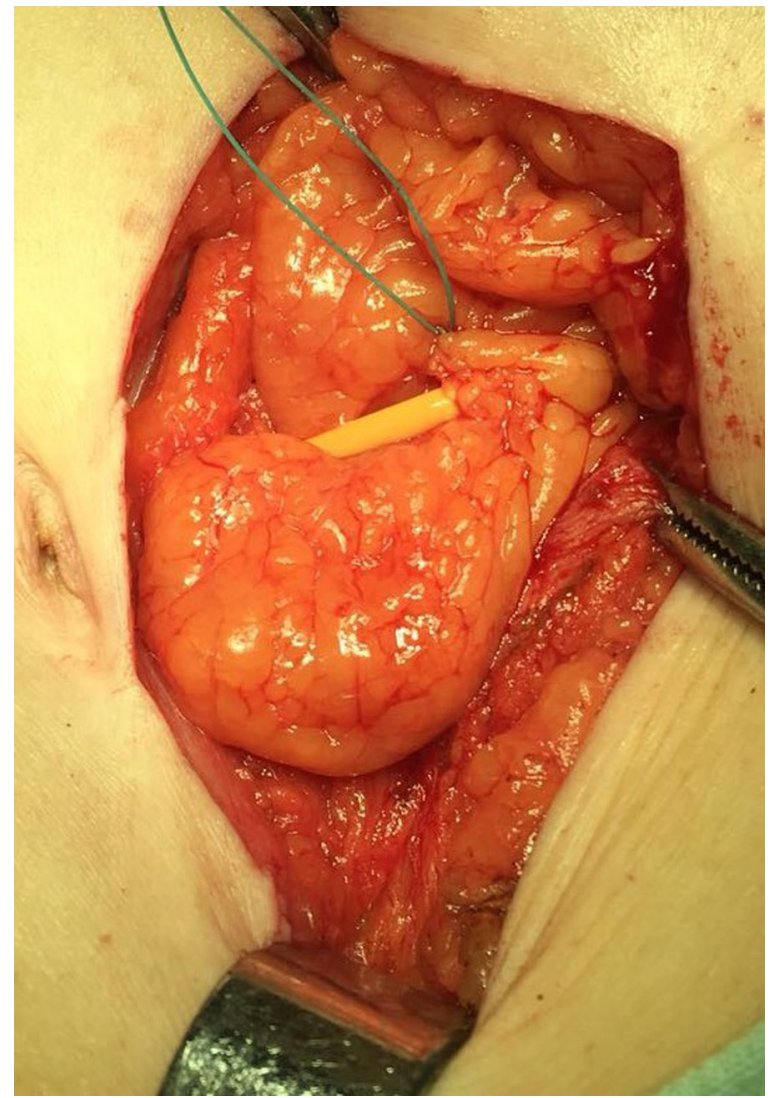

Fig. 6 - Intraoperative aspect. Anchoring the distal catheter to the greater omentum.

have also been used. In 1956, Picaza reported a surgical technique of lumboperitoneal shunt, with distal end of the catheter placed into the posterior peritoneal retro-omental space [16]. Some time later, endoscopically assisted techniques for the retroperitoneal placement of the lumboperitoneal shunt were introduced [17]. Matushita et al. placed the distal end of the catheter into the omental bursa [18]. Rengachary performed a transthoracic transdiaphragmatic ventriculoperitoneal shunt, inserting the distal tube into the infradiaphragmatic suprahepatic space [19]. Svoboda used the falciform ligament to fix the distal catheter above the liver and thus avoid the free movement of the tube within the peritoneal cavity [20].

On our series of 15 cases, we report a new surgical technique, the VEp shunt, in which the distal tip of the catheter is introduced and fixed in place between the two omental layers, isolated from the abdominal viscera. We previously reported the same surgical technique in an animal model [15].

In normal conditions, the daily production of CSF varies with age, being heavily influenced by underlying pathology. The average rate of production in an adult is around $0.3 \mathrm{ml} /$ min, leading to a total amount of $450 \mathrm{ml} /$ day, with a turnover of 3 times per day [21]. The peritoneum and greater omentum are capable of absorbing fluids through lymphatic vessels and blood capillaries [22]. This capacity of the peritoneum to absorb large amounts of fluids is already employed in the 
peritoneal dialysis in some of the patients with chronic renal failure. The epiploon (or greater omentum) could therefore be capable of absorbing the CSF quantities drained within it in their entirety, or at least in their majority. Considering the safety of epiplooic fenestration, this would allow for an efficient method of CSF inflow and absorption.

The surgical technique required for the VEp shunt is slightly more challenging than the classic VP shunt, since it implies the exploration of the peritoneal cavity and the greater omentum, a more extensive dissection of the latter, and the insertion of the catheter between the two epiplooic layers. Additionally, the condition of previous several shunt revisions may in itself pose a more difficult access of the peritoneal cavity, in terms of approach. Notwithstanding these hindrances, a neurosurgeon must be familiar with the abdominal cavity in order to attempt such a delicate procedure. For these reasons, we chose to manage these patients within a multidisciplinary team. The first half of the team, comprised of neurosurgeons, performed the cranial step, whereas the second half, represented by general surgeons, continued with the abdominal step. Having the second step made by an accomplished general surgeon, as complicated as it may seem, carries minimal surgical risks and postoperative complications.

We performed the VEp shunt regardless of gender, and within a wide range of age groups, varying from 6 to 70 years. All types of hydrocephalus can be observed in our series of cases, whether congenital, secondary, or of normal pressure.

This surgical technique is very useful in patients with repetitive distal shunt failures and multiple distal shunt revisions. This category of patients develops extensive viscero-peritoneal adherences, and they are prone to frequent recurrent distal shunt malfunctions. Patients with extensive peritoneal adherence syndrome, recurrent CSF pseudocysts or distal shunt occlusion with debrides are the main candidates who can benefit following VEp shunt. For them, it could represent a lifesaving procedure, especially after repetitive abdominal complications, since the distal catheter is placed in an adherence-free environment.

The VEp shunt can also be performed as the first line treatment of hydrocephalus, in patients with high risks for developing distal shunt malfunctions. As human CSF is irritating, it can cause local inflammation, peritoneal congestion and ultimately inflammatory adherences between catheter and abdominal viscera, in some cases leading to an extensive peritoneal adherence syndrome [2]. This mechanism explains the incidence of shunt-related morbidity. We decided to choose this type of shunt because the two patients had a high risk of developing distal shunt complications, due to their history of open abdominal surgery (previous hysterectomy, and cholecystectomy plus appendectomy, respectively). Patients with a history of extensive abdominal surgery and VPS are generally prone to distal shunt failure, and in our two cases the exploration of the abdominal cavity revealed vast peritoneal adherences. So in patients with history of open abdominal surgery, considered to have high risk of developing distal shunt malfunction, the VEp shunt is indicated as the first CSF drainage procedure, in order to prevent abdominal complications occurrence.

Young patients with plurimalformative syndromes harbor an elevated risk for developing recurrent abdominal complica- tions after VP shunts, owing to their inherent high friability of visceral walls and diminished visceral mobility [2]. In our series of cases, aside from congenital hydrocephalus, all five pediatric patients presented additional developmental anomalies, such as porencephalic cysts, agenesis of the corpus callosum, pineal region cysts, posterior fossa arachnoid cyst, Dandy-Walker malformation or Chiari II malformation and lumbar myelomeningocele. This particular subgroup of patients had a long and impressive history of repeated shunt revisions. All of them had more than 20 shunt revisions, with a high rate of distal shunt failures. Repetitive abdominal shuntrelated complications led to extensive peritoneal adherence syndrome, even in patients lacking preceding abdominal viscera surgical management. Surgery for distal shunt complications becomes more invasive with the passage of time, since while the first attempt is as simple as utilizing the trocar technique to insert the distal end of the catheter into the peritoneal cavity, once complications have manifested (CSF pseudocyst or adherence syndrome, for example), the same technique would be hazardous and an open approach is needed.

The VEp shunt has a series of advantages compared to the classic VP shunts. The first protects the patient against any distal shunt complications of standard VP drainage. By performing the VEp shunt, the distal tip of peritoneal catheter is placed between the layers of the greater omentum and secured with a simple suture, thus the direct contact between it and the abdominal viscera is averted. The distal end of the catheter is no longer mobile within the peritoneal cavity, and it cannot be displaced by bowel movements. Therefore, adhesions between the end of the catheter and the abdominal viscera can no longer develop, thereby diminishing the incidence of shunt-related morbidity, as well as the rate of migration, exteriorization or torsion of the catheter, and secondary mechanical ileus caused by intestinal volvulation around the end of the catheter.

Visceral perforations rarely occur after VP shunt surgery, however this scenario is deemed extremely severe [23,24]. While early visceral perforations are caused by intraoperative errors, late perforations develop further in time, as a result of the irritant effect of the CSF [2], which allows catheter adherence to the surrounding viscera. Progressively, the visceral wall becomes thinned and, ultimately, perforated [25]. On the one hand, visceral perforations lead to peritonitis, while on the other hand, they can eventually produce severe cerebral septic complications with high mortality and morbidity, such as ventriculitis, meningoencephalitis, meningitis, abscesses, or empyema $[25,26]$. Again, by isolating the distal tip of the peritoneal catheter between the two layers of greater omentum, the risk of forming adherences is lessened, concurrently diminishing the risk for visceral perforations.

Shunt infections are the most frequent cause of shunt dysfunction, occurring in 10.5\% of cases [27]. Early shunt infections are the result of intraoperative contamination and can be actively prevented before the surgical act [28]. The pathogenesis of late shunt infections is represented by catheter colonization from an abdominal site. Because of the adherence, the thinned visceral walls are gradually eroded, allowing for bacterial colonization $[29,30]$. Shunt infections then cause 
additional adherences, straps, and fibrous reshuffling between peritoneal viscera. Patients with shunt infections are prone to developing CSF pseudocysts. Epiplooic nodes assist by limiting or stopping the septic process. In our series, we had one patient with a history of ventriculitis with Acinetobacter baumannii. Furthermore, if an unrelated abdominal septic disease occurs, the greater omentum prevents direct contact between the catheter and the septic process in the early stages. Hence, we can safely assume that by isolating the distal end of the catheter we diminish the risk of shunt infections.

In our series, the CSF pseudocyst was a common cause of distal shunt failure. CSF pseudocysts are generally rare, being reported in only $2.04-4.5 \%$ of cases with VP shunt $[31,32]$. Although the pathophysiology of CSF pseudocysts is under debate, the reported risk factors are represented by septic complications, history of abdominal surgery, repetitive distal shunt failures, previous CSF pseudocysts, hyperproteinnorrachia, fluid malabsorption of the peritoneum, and allergy to silicone [33,34]. Even silent clinical shunt infections may cause local peritonitis. As a response to the local inflammatory process, a fibrous tissue around the distal tip of the catheter occurs. The fibrous tissue, lacking an epithelial lining, completely isolates the distal end of the catheter, forming a false cyst in which CSF is drained. Shunt infection was proven in many patients with CSF pseudocysts [32]. The patient with a history of ventriculitis with Acinetobacter baumannii, presented recurrent CSF pseudocysts and extensive peritoneal adherences. History of CSF pseudocyst is not a contraindication for VP shunting, however these patients frequently develop recurrent CSF pseudocysts. VEP shunt permits further shunting into the abdominal cavity, and by isolating the catheter end into the epiploon, the CSF in not drained directly into the peritoneal cavity. Thereby, the formation of adherences between abdominal viscera is prevented. In our series, we found a small group of patients, most of them children that presented recurrent CSF pseudocysts. We also observed that once a patient had developed a CSF pseudocyst, there is a predisposition for this complication to reoccur.

CSF ascites are rarely reported in patients with VP shunts [35]. Altered peritoneal capacity of fluid absorption, allergy to silicon, shunt infection, hyperproteinnorrachia, increased production of CSF, peritoneal metastasis are incriminated in the pathopysiology of CSF ascites.

Inguinal hernia may also occur in infants and young children, in which the processus vaginalis is still patent, being favored by increased abdominal pressure the malabsorption of the fluid in the peritoneum $[24,36]$. Constant intraperitoneal declivitous CSF flow maintains an increased abdominal pressure, which keeps the processus vaginalis patent. Using the VEp shunt, an important amount of fluid is absorbed before flowing into the abdominal cavity, and permits safe closing of procesus vaginalis.

\section{Conclusions}

Ventriculo-epiplooic (VEp) shunt is a new, safe and efficient surgical technique for the treatment of hydrocephalus. In this procedure, the distal tip of the peritoneal catheter is intro- duced between the two omental layers. The distal tip is isolated from abdominal viscera; therefore complications specific to VP shunts can be prevented. VEp shunting is indicated and may represent a saving option in patients with previous VP shunts and multiple distal failures due to repetitive abdominal complications. It is also indicated in patients with history of open abdominal surgery, which have high risk of developing abdominal complications. The VEp shunt allows the preservation of the abdominal cavity for the purpose of distal shunting for patients in which classic techniques carry high morbidity. We encountered no distal shunt revisions in our series. Postoperative results and followups, both short and long-term, were favorable.

\section{Patient consent}

The patients or patients' families were informed, and they approved and signed an informed consent form.

\section{Conflicts of interest}

None declared.

\section{Acknowledgement and financial support}

None declared.

\section{Ethics}

The work described in this article has been carried out in accordance with The Code of Ethics of the World Medical Association (Declaration of Helsinki) for experiments involving humans; Uniform Requirements for manuscripts submitted to Biomedical journals.

\section{R E F E R E N C E S}

[1] Nelson SL. Hydrocephalus. eMedicine [eMedicine Specialties/Neurology/Behavioral Neurology and Dementia] 2016.

[2] Popescu M, Grigorean VT, editors. Hidrocefalia. Bucharest: Ed Univ Carol Davila; 2006.

[3] Greenberg MS. Hydrocephalus. In: Greenberg MS, editor. Handbook of neurosurgery. New York: Thieme Medical Publishers; 2010. p. 307-40 [chapter 15].

[4] Del Bigio MR. Epidemiology and direct economic impact of hydrocephalus: a community based study. Can J Neurol Sci 1998;25:123-6.

[5] Lifshultz JI, Johnson WD. History of hydrocephalus and its treatments. Neurosurg Focus 2001;11:E1.

[6] Chakraborty A, Drake JM, Warf BC. Methods for cerebrospinal fluid diversion in pediatric hydrocephalus: from shunt to scope. In: Quinones-Hinojosa A, editor. Schmidek \& Sweet Operative Neurosurgical Techniques. Elsevier Saunders; 2012. p. 1231-43 [chapter 54].

[7] Olavarria G, Reitman AJ, Glodman S, Tomita T. Post-shunt ascites in infants with optic chiasmal hypothalamic 
astrocytoma: role of ventricular gallbladder shunt. Childs Nerv Syst 2005;21:382-4.

[8] Novelli PM, Reigel DH. A closer look at the ventriculogallbladder shunt for the treatment of hydrocephalus. Pediatr Neurosurg 1997;26:197-9.

[9] Porter RW, Detwiler PW, Rekate HL. Hydrocephalus in children. In: Kaye AH, Black P, editors. Operative neurosurgery. London: Harcourt Publishers Limited; 2000. p. 1215-33 [chapter 100].

[10] Ming Wo PY, Hung PK, Chan KY, Chin Kwok JK. Ventriculosternal shunting for the management of hydrocephalus: case report of a novel technique. Neurosurgery 2015;11(Suppl 3):371-5.

[11] Petraglia AL, Morovan MJ, Dimopoulos VG, Silberstein HJ. Ventriculosubgaleal shunting - a strategy to reduce the incidence of shunt revisions and slit ventricles: an institutional experience and review of the literature. Pediatr Neurosurg 2011;47:99-107.

[12] Demetriades AK, Hag IZ, Jarosz J, McCormick D, Bassi S. The ventriculocholecystic shunt: two case reports and a review of the literature. Br J Neurosurg 2013;27:505-8.

[13] Elwatidy SM. Ventriculo-sagittal sinus shunt malfunction. Causes of failure, avoidance, and alternatives. Neurosciences (Riyadh) 2009;14:172-4.

[14] Hamm S, Kim BH, Lee CH, Hwang K, Park YM, Kim SL. Ventriculotransverse sinus shunt for hydrocephalus. J Korean Neurosurg Soc 1993;22:520-8.

[15] Grigorean VT, Popescu M, Sandu AM, Toader S. Ventriculoepiplooic shunt, a new surgical technique for treatment of hydrocephalus. J Exp Med Surg Res 2010;17:55-63.

[16] Picaza JA. The posterior-peritoneal shunt technique for the treatment of internal hydrocephalus in infants. J Neurosurg 1956;13:289-93.

[17] Kubo S, Ueno M, Takimoto H, Karasawa J, Kato A, Yoshimine T. Endoscopically aided retroperitoneal placement of a lumboperitoneal shunt. Technical note. J Neurosurg 2003;98:430-3.

[18] Matushita H, Cardeal D, Pinto FC, Plese JPP, de Miranda JS. The ventriculoomental bursa shunt. Childs Nerv Syst 2008;24:949-53.

[19] Rengachary SS. Transdiaphragmatic ventriculoperitoneal shunting: technical case report. Neurosurgery 1997;41:695-7.

[20] Svoboda SM, Park H, Naff N, Dorai Z, Williams MA, Youssef Y. Preventing distal catheter obstruction in laparoscopic ventriculoperitoneal shunt placement in adults: the "falciform technique". J Laparoendosc Adv Surg Tech A 2015;25:642-5.

[21] Greenberg MS. Cerebrospinal fluid. In: Greenberg MS, editor. Handbook of neurosurgery. New York: Thieme Medical Publishers; 2010. p. 297-306 [chapter 14].
[22] Stachowska-Pietka J, Waniewski J, Flessner MF, Lindholm B. Distributed model of peritoneal fluid absorption. Am J Physiol Heart Circ Physiol 2006;291:H1862-7.

[23] Kin S, Imamura J, Ikeyama Y, Jimi Y, Yasukura S. Perforation of the intestine by a peritoneal tube 10 years after a ventriculo-peritoneal shunt. No Shinkei Geka 1997;25:573-5.

[24] Tamburrini G, Caldarelli M, Di Rocco C. Diagnosis and management of shunt complications in the treatment of childhood hydrocephalus. Rev Neurosurg 2002;1(3).

[25] Ibrahim AW. E. coli meningitis as an indicator of intestinal perforation by V-P shunt tube. Neurosurg Rev 1998;21:194-7.

[26] Byard RW, Kosyzca B, Qiao M. Unexpected childhood death due to a rare complication of ventriculoperitoneal shunting. Am J Forensic Med Pathol 2001;22:207-10.

[27] Reddy GK, Bollam P, Caldito G. Ventriculoperitoneal shunt surgery and the risk of shunt infection in patients with hydrocephalus: long-term single institution experience. World Neurosurg 2012;78:155-63.

[28] Kestle JR, Riva-Cambrin J, Wellons 3rd JC, Kulkarni AV, Whitehead W, Walker ML, et al. A standardized protocol to reduce cerebrospinal fluid shunt infection: the Hydrocephalus Clinical Research Network Quality Improvement Initiative. J Neurosurg Pediatr 2011;8:22-9.

[29] Baird C, O'Conner D, Pittman T. Late shunt infection. Pediatr Neurosurg 1999;31:269-73.

[30] Borgbjerg BM, Gjerris F, Albeck MJ, Borgensen SE. Risk of infection after cerebrospinal fluid shunt: an analyisis of 884 first-time shunts. Acta Neurochir 1995;136:1-7.

[31] Sanal M, Laimer E, Haussler B, Hager J. Abdominal cerebrospinal fluid pseudocysts in patients with ventriculoperitoneal shunts: 30 years of experience. J Indian Assoc Pediatr Surg 2007;12:214-7.

[32] Rainov N, Schobess A, Heidecke V, Burkert W. Abdominal CSF pseudocysts in patients with ventriculo-peritoneal shunts. Report of fourteen cases and review of the literature. Acta Neurochir (Wien) 1994;127:73-8.

[33] Gaskill SJ, Marlin AE. Pseudocysts of the abdomen associated with ventriculoperitoneal shunts: a report of twelve cases and a review of the literature. Pediatr Neurosci 1989;15:23-7.

[34] Adegbite AB, Khan M. Role of protein content in CSF ascites following ventriculoperitoneal shunting. J Neurosurg 1982;57:423-5.

[35] Chidambaram B, Balasubramaniam V. CSF ascites: a rare complication of ventriculoperitoneal shunt surgery. Neurology India 2000;48:378-80.

[36] Clarnette TD, Lam SK, Hutson JM. Ventriculo-peritoneal shunts in children reveal the natural history of closure of the processus vaginalis. J Pediatr Surg 1998;33:413-6. 